\title{
Herbicides doses in the defoliation of common bean to anticipate mechanized harvesting
}

\author{
José Geraldo da Silva ${ }^{\mathrm{a}}$, Adriano Stephan Nascente ${ }^{\mathrm{a}}{ }_{\odot}$, Pedro Henrique Lopes Sarmento $^{\mathrm{a}}{ }_{\odot}$ \\ a Embrapa Arroz e Feijão, Santo Antônio de Goiás, GO, Brazil.
}

\begin{abstract}
Background: The use of desiccant herbicides can allow the anticipation of common bean harvesting by providing a reduction in the humidity of plants and grains.

Objective: Determine the effect of doses of desiccant herbicides on the moisture content of the plants (stems, leaves and grains), in the 100 grains mass, grain yield and physiological quality of the seeds of two contrasting common bean cultivars.
\end{abstract}

Methods: The experimental design for each cultivar (BRS FC 104, super early cycle, 60 days from sowing to harvesting and BRS Estilo, normal cycle, 90 days from sowing to harvesting) as in randomized blocks in the factorial scheme $4 \times 3 \times 4$, with four replications. Treatments consisted of four herbicides (ammonium glufosinate (200 $\mathrm{g} \mathrm{L}^{-1}$ of active ingredient, ai), glyphosate ( $480 \mathrm{~g} \mathrm{~L}^{-1}$ of acid equivalent), diquat $\left(200 \mathrm{~g} \mathrm{~L}^{-1}\right.$ of ai) and paraquat (200 $\mathrm{g} \mathrm{L}^{-1}$ of ai), with three doses $\left(200 \mathrm{~g} \mathrm{~L}^{-1}, 400 \mathrm{~g} \mathrm{~L}^{-1}\right.$ and $600 \mathrm{~g} \mathrm{~L}^{-1}$ of ai per ha for ammonium glufosinate, diquat and paraquat, and $480 \mathrm{~g} \mathrm{~L}^{-1}$, $960 \mathrm{~g} \mathrm{~L}^{-1}$ and 1,440 $\mathrm{g} \mathrm{L}^{-1}$ of ae per ha for glyphosate) with evaluations of the variables at $0,3,5$ and 7 days after application of the herbicide.

Results: All desiccants used provided faster drying of the botanical structures allowing faster harvesting in relation to control plants. The dosage of $200 \mathrm{~g} \mathrm{~L}^{-1}$ of the ai ha ${ }^{1}$ in the cultivar BRS FC 104 and $1,440 \mathrm{~g} \mathrm{~L}^{-1}$ of ae per ha for glyphosate and $600 \mathrm{~g} \mathrm{~L}^{-1}$ of ai per ha for the others dessicants in the cultivar BRS Estilo were those that provided best plant drying. The use of desiccants in plants of common bean did not affect crop grain yield. The dosage of $600 \mathrm{~g} \mathrm{~L}^{-1}$ of ai per ha of the ammonium glufosinate desiccant provided a reduction in vigor and normal seedlings and an increase in abnormal seedlings in the cultivar BRS FC 104.

Conclusion: All desiccant herbicides used allowed anticipation of common bean harvesting.

Keywords: Phaseolus vulgaris; Desiccants; Ammonium Glufosinate; Glyphosate; Diquat; Paraquat

Journal Information:

ISSN - 2675-9462

Website: http://awsjournal.org

Journal of the Brazilian Weed Science Society

How to cite: Silva JG, Nascente AS, Sarmento PHL. Herbicides doses in the defoliation of common bean to anticipate mechanized harvesting. Adv Weed Sci. 2021;39:e21237358 https://doi.org/10.51694/AdvWeedSci/2021;39:00009

Approved by:

Editor in Chief: Anderson Luis Nunes

Conflict of interest: The authors have no conflicts of interest to declare in relation to the research presented.

Received: April 29, 2020

Approved: February 17, 2021

* Corresponding author: <adriano.nascente@embrapa.br>

\section{(c) (1)}

This is an open-access article distributed under the terms of the

Creative Commons Attribution License, which permits unrestricted use, distribution, and reproduction in any medium, provided that the original author and source are credited.

Copyright: 2021

\section{Introduction}

Common bean (Phaseolus vulgaris L.) is the main source of vegetable protein for direct consumption by the low-income population (Ganascini et al., 2019). The cultivation of common beans in Brazil is carried out in three harvesting period; the first is called "summer harvesting", the second "off-season harvesting" and the third "winter harvesting". In the growing season 2018/2019 the common bean planted area in Brazil was about three million hectares, distributed over the three harvesting periods, which was 944,000 ha in the summer harvesting, 1.5 million ha in the offseason harvesting and 578,000 ha in the winter harvesting (Conab, 2020).

Among the stages of crop development, harvesting time is one of the most important since, if it is not done properly, it can cause losses, mechanical damage and cause the browning of the grains, which interfere in grain quality and in the commercial value (Souza et al., 2004). The best time for harvesting common bean seeds is just after physiological maturity, a time when the seeds have high vigor, germination and maximum accumulation of dry matter (Coelho et al., 2012; Lamego et al., 2013; Santos et al., 2005). However, at this stage, the seeds have a high moisture content (above 40\%) and the plant is still with green and moist leaves and stems. With these characteristics, mechanized harvesting is impaired, as it can cause mechanical damage to seeds (Coelho et al., 2007) and poor performance of harvesting machines (Silva et al., 2017). Assis et al. (2019) reported that harvesting common beans with humidity above $18 \%$ causes damage to the grains by smashed.

Thus, to avoid losses in the common bean harvesting, the farmer has to wait for the plants to dry and reduce the moisture content of the grains (Muasya et al., 2002). Therefore, the seeds remain in the field for longer than the physiological maturation phase, and are exposed to environmental variations in temperature and humidity, which can negatively affect soil quality (Lacerda et al., 2005), as the loss and gain of seed water decreases its germination potential and vigor (Lamego et al., 2013).

Studies related to pre-harvest desiccation for seed production have been carried out mainly in crops such as rice (He et al., 2015), common beans (Coelho et al., 2012; McNaughton et al., 2015; Tavares et al., 2016; Zagonel et al., 2002) and soybean (Guimarães et al., 2012; Kappes et al., 2009, 2012; Silva and Rosa, 2016). This application of pre-harvest desiccant herbicides minimizes the deterioration and loss 
of grain quality of crops by standardizing the maturation and dehydration of plants and seeds and, therefore, enabling faster harvesting and reducing the exposure of seeds to weather conditions and attack by pests and diseases (Assis et al., 2019; Kappes et al., 2009; Lacerda et al., 2003; Pelúzio et al., 2008). The use of desiccant can provide anticipation of the harvest by up to seven days without causing reductions in the crop grain yield (Daltro et al., 2010; Kappes et al., 2009). However, some important aspects must be considered in a seed production system when desiccants are used, such as: mode of action and rate of the desiccant, environmental conditions, phenological stage of the crop at the time of desiccant application and influence on the germination and vigor of seeds (Lacerda et al., 2005).

However, there are still few studies to determine the best rate of herbicides used in the bean crop in order to anticipate the harvesting, avoid losses in productivity and preserve the physiological quality of the seeds. Besides, some farmers are using glyphosate to make this dessication without recommendation. The objective of this work was to determine the effect of doses of desiccant herbicides on the moisture content of the plants (stems, leaves and grains), in the mass of 100 grains, grain yield and physiological quality of the seeds of two common bean cultivars.

\section{Material and methods}

The experiments were conducted in the winter season of the years 2018 and 2019 at Capivara Farm, located in the municipality of Santo Antônio de Goiás, GO, at $16^{\circ} 28^{\prime} 00$ “S and $49^{\circ} 17^{\prime} 00$ " W, and $823 \mathrm{~m}$ altitude. The region's climate is tropical savannah, and is considered Aw type according to the Köppen classification. There are two well-defined seasons, usually dry from May to September (autumn/ winter) and rainy from October to April (spring / summer), the average annual rainfall is between 1,500 to $1,700 \mathrm{~mm}$. The average annual temperature is $22.7^{\circ} \mathrm{C}$, varying annually from $14.2^{\circ} \mathrm{C}$ to $34.8^{\circ} \mathrm{C}$.

The experimental areas were cultivated for five growing season under no-tillage systems, with corn/ soybeans grown in the summer and common beans in the winter. The soil in the experimental areas was classified as an Oxisol. Before deployment of the experiments, in June 2018 and 2019 as well, soil was sampled at a depth of $0-0.20 \mathrm{~m}$ and then, chemical analyzes in this soil were carried out to characterize the experimental area (Table 1). Chemical

\begin{tabular}{|c|c|c|c|c|c|c|}
\hline & $\mathrm{pH}$ & Ca & $\mathrm{Mg}$ & $P$ & K & $\mathrm{SOM}^{1}$ \\
\hline Year & in $\mathrm{H}_{2} \mathrm{O}$ & --------ח & & n------ & -1------ & $\mathrm{g} \mathrm{kg}^{-1}$ \\
\hline 2018 & 5.4 & 26.0 & 10.1 & 12.4 & 92 & 34.3 \\
\hline 2019 & 6.0 & 15.1 & 12.7 & 13.0 & 171 & 32.7 \\
\hline
\end{tabular}

1Soil organic matter. analyzes were performed according to the methodology proposed by Donagema et al. (2011).

Two experiments were conducted, one in 2018, with the cultivar BRS FC 104 (super early life cycle, around 60 days), and another in 2019, with the cultivar BRS Estilo (normal life cycle, around 90 days). In both experiments, a randomized block design was used in the factorial scheme with four replications. In 2018, the treatments consisted of a combination of three desiccants (ammonium glufosinate (200 $\mathrm{g} \mathrm{L}^{-1}$ of active ingredient, ai) (Finale ${ }^{\circledR}$ ), diquat (200 $\mathrm{g} \mathrm{L}^{-1}$ of ai), (Reglone ${ }^{\circledR}$ ) and paraquat (Gramoxone $\left.{ }^{\circledR}\right)\left(200 \mathrm{~g} \mathrm{~L}^{-1}\right.$ of ai), with three doses $\left(200,400\right.$ and $600 \mathrm{~L} \mathrm{ha}^{-1}$ of the active ingredient) and four times for determining the variables ( $0,3,5$ and 7 days after application of the herbicide). In 2019, the factors were the same, however, the glyphosate desiccant (480 $\mathrm{g} \mathrm{L}^{-1}$ of acid equivalent) (Glyphosate ${ }^{\circledR}$ ) was added using the levels of 480,960 and $1,440 \mathrm{~g} \mathrm{~L}^{-1}$ of the acid equivalent per ha. Additionally, in each experiment the control treatment was used, in which the common bean plants were not dried with herbicides. The spraying of herbicides was carried out using a manual sprayer with a pressure supplied by a $\mathrm{CO}_{2}$ pressured source and a type of conical nozzle (TX-VS2). Climatic conditions and at the time to apply the herbicides environmental conditions were with high temperatures $\left(>30^{\circ} \mathrm{C}\right.$ ) and low humidity (less than 30\%).

The sowing of common bean cultivars BRS FC 104 and BRS Estilo was carried out by a no-till seeder with five planting rows, spaced $0.45 \mathrm{~m}$ apart and regulated to distribute 10 viable seeds per meter. The machine was equipped with a furrower and was always operated in the same direction, at a speed of $4 \mathrm{~km} \mathrm{~h}^{-1}$. The experiments were installed in the first half of June, in both years. Fertilization was carried out in accordance with the soil analysis and with the recommendations of Sousa and Lobato (2004), with $320 \mathrm{~kg} \mathrm{ha}^{-1}$ of the formulated 5-30-15 $\left(\mathrm{N}-\mathrm{P}_{2} \mathrm{O}_{5}-\mathrm{K}_{2} \mathrm{O}\right)$, which was placed in the sowing furrow). The topdressing fertilization was carried out with $60 \mathrm{~kg} \mathrm{ha}^{-1}$ of nitrogen as urea. The central pivot sprinkler irrigation system was used, and water management was performed according to the crop needs (Silveira and Stone, 2001). The sanity management of the crop was carried out according to the needs to keep the plants free of insects, diseases and weeds (Vieira et al., 2006). Therefore, when necessary, it was applied the recommended product to control insects, diseases and weeds.

In the experiments, the drying rate of the botanical structures of the plants (stems + leaf, pods + grains, whole plant) was determined; mass of 100 grains; the germinate index of the seeds and the grain yield. Effect of plant desiccation was carried out on samples of five plants in each plot, taken immediately before the desiccant application and at three, five and seven days after application. The analyzed plants were harvested close to the soil and then separated into two fractions, stems with leaves and pods with grains. Each fraction of the plant was weighed to obtain 
the wet weight and, later, it was placed in the greenhouse at a temperature of $65{ }^{\circ} \mathrm{C}$, where it remained until the constant mass. The water content of the plant fractions was determined (equation 1 ).

$$
W C=\frac{(M 1-M 2) \cdot 100}{M 1} \text {, where: }
$$

$\mathrm{WC}=$ water content in plants $(\%)$

M1 = wet mass of plant botanical structures $(\mathrm{g})$

M2 = dry mass of plant botanical structures $(\mathrm{g})$

Also on the seventh day after desiccation, plants were harvested, in $2 \mathrm{~m}$ from the central row, from each plot to determine the mass of 100 grains, the germinate index of the seeds and the grain yield of the bean. The mass of 100 grains and productivity were expressed in grams and $\mathrm{kg}$ ha ${ }^{1}$, respectively, after the water content was corrected to 130 $\mathrm{g} \mathrm{kg}^{-1}$. The germinate index of the seeds was evaluated at 30 days after common bean harvesting.

The data obtained were submitted to analysis of variance and when detected significance, the averages were compared by the Tukey test at $p<0.01$. In addition, Dunnett's test was performed to compare each treatment with the control treatment. In the quantitative factor (days after applying desiccant) we performed a regression analyses.

\section{Results and discussion}

In the cultivar BRS FC 104 there was isolated effect of the days after the application of the desiccant for the moisture content in the variables stem + leaf, pods + grains, and in the whole plant, and there was no effect on the mass of 100 grains (Table 2). Thus, after the application of the desiccant, the plant start to lose water and the moisture content decreased day after day in all botanic structure. Comparing the moisture content of botanical structures with the control treatment (without the application of desiccant), it appears values was significantly lower in the plants where desiccant was applied than in the control plants (Figure 1). According to several authors, the application of desiccant herbicides during physiological maturation can provide several benefits that favor faster harvesting, such as reducing the deterioration and loss of grain quality of crops by standardizing the maturation and dehydration of plants and seeds, reducing the exposure of seeds to the weather and attack of pests and diseases (Assis et al., 2019; Kappes et al., 2009; Lacerda et al., 2003; Pelúzio et al., 2008). According to Silva et al. (2017), the ideal time for harvesting common beans is when the grains have a moisture content between 18 and $24 \%$. It was observed that at seven days after dessicant application, the moisture content of grains and pods was $21.4 \%$, that is, suitable for harvesting, whereas in the control treatment plants, these values were at $37.1 \%$. The use of desiccant applied during physiological maturation can provide an advance of the harvest by up to seven days (Daltro et al., 2010; Kappes et al., 2009).
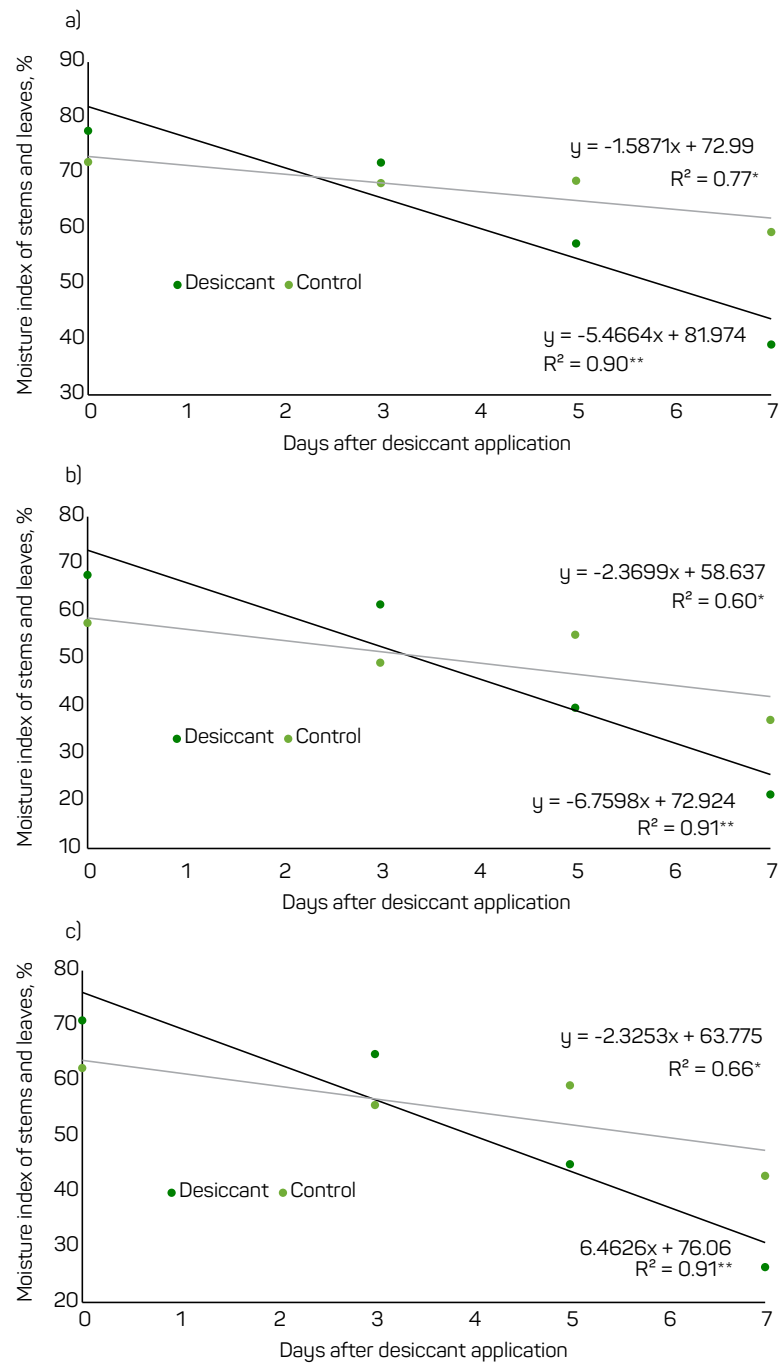

Figure 1 - Moisture content of botanical structures of common bean cultivar BRS FC 104, leaves and stems (A), grains and pods $(B)$ and whole plant $(C)$ depending on the days after the desiccant application.

In the cultivar BRS FC104, the desiccation of plants for mechanized harvest was not affected by the herbicide type (Table 2). Thus, the three desiccants were equally efficient as they provided a reduction in the moisture content of the plant's botanical structures. These three desiccants act on photochemical reactions, with diquat and paraquat acting on photosystem I (Zagonel et al., 2002) and ammonium glufosinate acts on the enzyme glutamine, which acts on the synthesis of the nitrogen assimilation pathway (Brunharo et al., 2014). The cultivar BRS FC104 has a type II growth habit, being erect and with an average height of $18 \mathrm{~cm}$ (Melo et al., 2017). Thus, the exposure of plants to sunlight may have contributed to the faster drying of the common bean plants as observed in this experiment. Similar results of fast drying of the common bean plants due dessicant application were also observed by Silva et al. (2017). 
Table 2 - Moisture content of plant botanic structure (\%) and mass of 100 grains (g) of common bean, cultivar BRS FC 104, as affected by the type of the desiccant used in the pre-harvest, the application dose and the number of days after desiccation.

\begin{tabular}{|c|c|c|c|c|}
\hline Factors & $\begin{array}{l}\text { Stem } \\
\text { and } \\
\text { Leaves }\end{array}$ & $\begin{array}{l}\text { Pods } \\
\text { and } \\
\text { grains }\end{array}$ & $\begin{array}{l}\text { Whole } \\
\text { plant }\end{array}$ & M100 \\
\hline Desiccant & \multicolumn{3}{|c|}{----Moisture index \%---- } & grams \\
\hline Ammonium glufosinate & 61.2 & 46.5 & 51.0 & $27.3 a$ \\
\hline Paraquat & 64.2 & 47.3 & 53.6 & $28.7 b$ \\
\hline Diquat & 59.1 & 49.0 & 50.9 & 27.4 a \\
\hline
\end{tabular}

\begin{tabular}{|l|c|c|c|c|}
\hline Factors & \multicolumn{4}{|c|}{ F probability (p< 0.05) } \\
\hline Desiccant (De) & $\mathrm{ns}$ & $\mathrm{ns}$ & $\mathrm{ns}$ & $*$ \\
\hline Dose (Ds) & $\mathrm{ns}$ & $\mathrm{ns}$ & $\mathrm{ns}$ & $\mathrm{ns}$ \\
\hline DADA & $*$ & $*$ & $*$ & $\mathrm{~ns}$ \\
\hline De $\times$ Ds & $*$ & $*$ & $*$ & $\mathrm{~ns}$ \\
\hline De $\times$ DADA & $\mathrm{ns}$ & $\mathrm{ns}$ & $\mathrm{ns}$ & $\mathrm{ns}$ \\
\hline Ds $\times$ DADA & $\mathrm{ns}$ & $\mathrm{ns}$ & $\mathrm{ns}$ & $\mathrm{ns}$ \\
\hline De $\times$ Ds xDADA & $\mathrm{ns}$ & $\mathrm{ns}$ & $\mathrm{ns}$ & $\mathrm{ns}$ \\
\hline CV & 14.3 & 20.2 & 17.2 & 8.1 \\
\hline
\end{tabular}

Means followed by the same letter in the column, do not differ by Tukey's test ( $p<0.05)$. ns - not significant. * significant at $p<0.05$. DADA - Days after desiccant application.

There was an interaction between the desiccant doses and the moisture content in the botanical structures (Table 2). Thus, in most evaluations, the moisture content of botanical structures was similar among the desiccants for the different doses (Table 3). Therefore, from the point of view of the farmers, the best would be to use of the lowest doses that contribute to reducing the cost of production. However, the dosage of $200 \mathrm{~g} \mathrm{~L}^{-1} \mathrm{ha}^{-1}$ of the active ingredient is slightly less than the manufacturer's recommendation; this can be explained because the common bean was harvested in September, a time with high temperatures and low relative humidity that favors more rapid drying of material in the field.

\begin{tabular}{|c|c|c|c|}
\hline \multirow{3}{*}{ Desiccant } & \multicolumn{3}{|c|}{ Dose (L ha-1). } \\
\hline & 1 & 2 & 3 \\
\hline & \multicolumn{3}{|c|}{ Stem + Leaves } \\
\hline Ammonium glufosinate & 64.8 aA & $61.4 \mathrm{aAB}$ & $57.4 \mathrm{aB}$ \\
\hline Paraquat & 64.6 aA & $64.4 \mathrm{aA}$ & 63.4 aA \\
\hline \multirow[t]{2}{*}{ Diquat } & 62.2аA & 53.5 bB & 61.8 aA \\
\hline & \multicolumn{3}{|c|}{ Pods + Grains } \\
\hline Ammonium glufosinate & 48.3 aA & 48.7 aA & 42.7 bA \\
\hline Paraquat & 50.3 aA & 50.0 aA & $46.7 \mathrm{abA}$ \\
\hline \multirow[t]{2}{*}{ Diquat } & 45.7 aA & $44.4 \mathrm{aA}$ & 51.7 aA \\
\hline & \multicolumn{3}{|c|}{ Whole plant } \\
\hline Ammonium glufosinate & 53.5 aA & 52.2 aA & 47.3 bA \\
\hline Paraquat & 54.9 aA & 54.3 aA & $51.6 \mathrm{abA}$ \\
\hline Diquat & 50.7 aAB & $47.1 \mathrm{aB}$ & 55.0 aA \\
\hline
\end{tabular}

Means followed by the same letter, lower case in the column or upper case in the row, do not differ by Tukey's test ( $p<0.05)$.
In the BRS Estilo cultivar, there was interaction between desiccant type and days after its application (Table 4). Thus, it appears that all botanical structures studied (leaves and stems, grains and pods, and the whole plant), as observed in the cultivar BRS FC104, the moisture content was higher in the control treatment compared to the desiccants used (Figure 2). These results reinforce the report of other authors who showed that the application of desiccant accelerates the drying of the plants and favors the anticipation of the harvest (Daltro et al., 2010; Kappes et al., 2012; Silva et al., 2017).

There was an effect of the doses of applied desiccants on the reduction of the water content of the leaves and stems, pods and grains, and the whole plant, and the maximum performance was achieved with the dose of $1,440 \mathrm{~g} \mathrm{~L}^{-1}$ of acid equivalent per ha and $600 \mathrm{~g} \mathrm{~L}^{-1}$ of active ingredient for the other dessicants (Table 4). The cultivar BRS Estilo has a normal cycle (cycle around 90 days from sowing to harvesting) and biomass production far superior to the cultivar BRS FC 104 (super early cycle, around 60 days from sowing to harvesting), with an average height of 40 $\mathrm{cm}$ (Melo et al., 2009). This may explain why in the dose of $200 \mathrm{~g} \mathrm{~L}^{-1}$ of active ingredient for the desiccants, the cultivar BRS FC 104 was completely dry and in the cultivar BRS Estilo, higher doses had to be applied.

Table 4 - Moisture content of plant botanic structure (\%)

and mass of 100 grains ( $\mathrm{g}$ ) of common bean, cultivar BRS

Estilo, as affected by the type of the desiccant used in the

pre-harvest, the application dose and the number of days

after desiccation.

\begin{tabular}{|c|c|c|c|c|}
\hline Factors & $\begin{array}{c}\text { Stem } \\
\text { and } \\
\text { Leaves }\end{array}$ & $\begin{array}{l}\text { Pods } \\
\text { and } \\
\text { grains }\end{array}$ & $\begin{array}{l}\text { Whole } \\
\text { plant }\end{array}$ & M100 \\
\hline Desiccant & \multicolumn{3}{|c|}{----Moisture index \%---- } & grams \\
\hline Ammonium glufosinate & 54.8 & 40.3 & 44.4 & 24.0 \\
\hline Paraquat & 62.4 & 46.3 & 52.2 & 24.0 \\
\hline Diquat & 61.9 & 47.6 & 52.2 & 23.9 \\
\hline Glyphosate & 61.3 & 48.8 & 52.6 & 23.9 \\
\hline \multicolumn{5}{|l|}{ Dose (g ae/ai L-1 ha-1) } \\
\hline $\begin{array}{l}200 \text { for other dessicants } \\
\text { and } 480 \text { for glyphosate }\end{array}$ & $61.9 b$ & $49.2 \mathrm{c}$ & $53.1 b$ & 23.9 \\
\hline $\begin{array}{l}400 \text { for other dessicants } \\
\text { and } 960 \text { for glyphosate }\end{array}$ & $60.9 b$ & $45.9 b$ & $50.5 b$ & 23.9 \\
\hline $\begin{array}{l}600 \text { for other dessicants } \\
\text { and } 1,440 \text { for glyphosate }\end{array}$ & 57.6 a & $42.3 \mathrm{a}$ & 46.7 a & 24.0 \\
\hline Factors & \multicolumn{4}{|c|}{ F probability $(p<0.05)$} \\
\hline Desiccant (De) & * & * & * & ns \\
\hline Dose (Ds) & * & * & * & ns \\
\hline DADA & * & * & * & ns \\
\hline De $\times$ Ds & ns & ns & ns & ns \\
\hline De $\times$ DADA & * & * & * & ns \\
\hline Ds $\times$ DADA & ns & ns & $\mathrm{ns}$ & ns \\
\hline De $\times$ Ds $\times$ DADA & ns & ns & ns & ns \\
\hline CV & 11.5 & 16.7 & 13.5 & 5.2 \\
\hline
\end{tabular}

Means followed by the same letter in the column, do not differ by Tukey's test $(p<0.05)$. ns - not significant. * significant at $p<0.05$. DADA - Days after desiccant application. CV Coefficient of variation. 

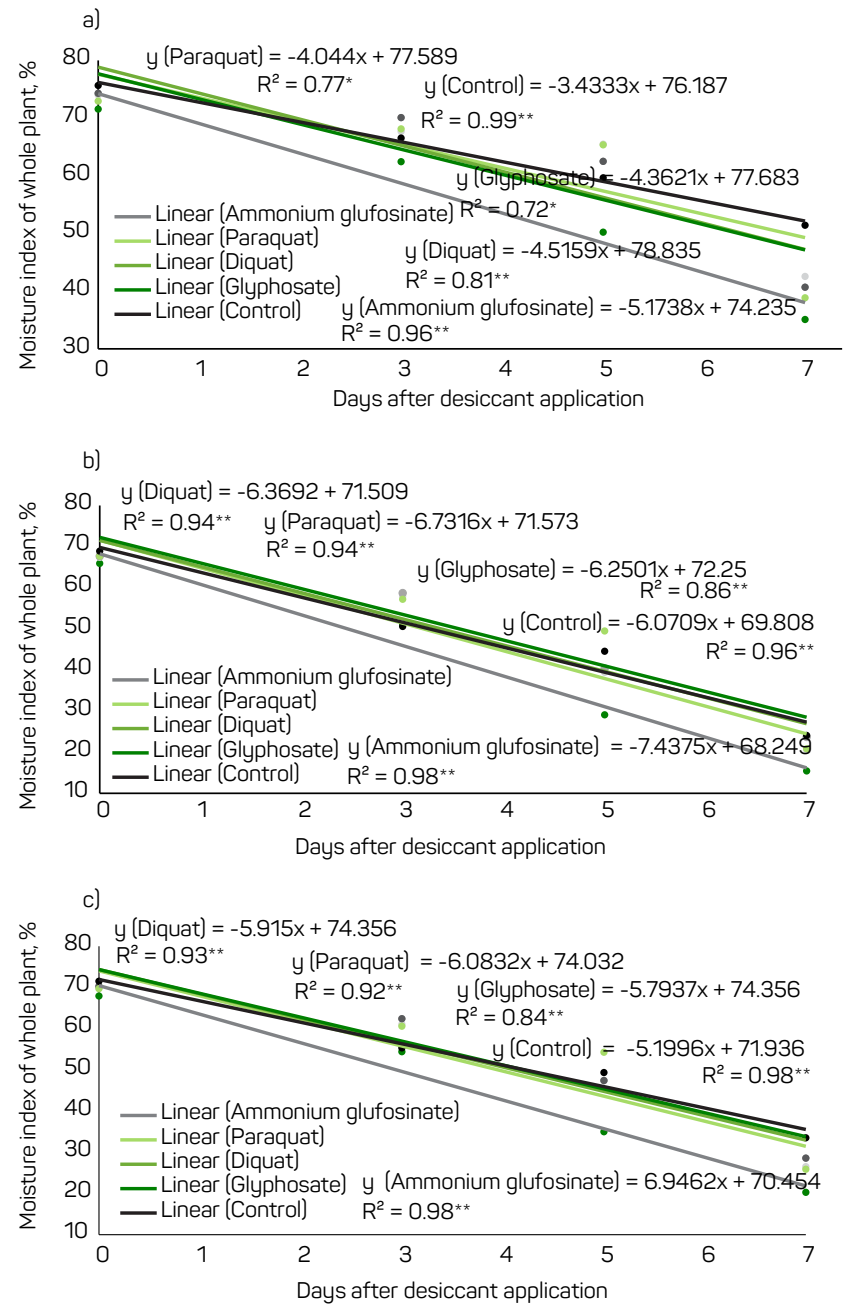

Figure 2 - Moisture content of botanical structures of common bean cultivar BRS Estilo, leaves and stems (A), grains and pods (B) and whole plant (C) depending on the desiccant used and the days after the desiccant application.

However, regardless of the dose and desiccant used, it appears that the harvest of common beans, meeting the recommendation for moisture content in the grains between 18 and 22\% (Silva et al., 2017), could be done at 7 days after physiological maturation/application of the desiccant. On the other hand, in treatments without the application of the desiccant, the harvest could be made 11 days after the physiological maturation, that is, only four days in relation to the treatments with the application of the desiccant. This is due to the environmental conditions of high temperatures and low humidity, in which the harvest was made in September and allowed the plants to dry quickly. For example, Silva et al. (2017) reported that the application of diquat provided the anticipation of the harvest in 29 days and the ammonium glufosinate, 22 days, when the harvest was made in Vargem Grande do Sul, SP in July, when the temperatures are much lower and the relative humidity of the air above the values found in September in the municipality of Santo Antônio de Goiás, GO. Given this result, the question comes, would it be necessary to carry out this desiccation to accelerate the harvest in a period when there is no rain in the Central Brazil region, and therefore, theoretically, there would be no rush to carry out the harvest, because the plants would not suffer from the weather. However, several authors warn that the application of desiccants is not only used to anticipate the harvest, but also to standardize the drying of the plants and improve the quality of the grain, since the common bean maturation is not uniform (Assis et al., 2019; Kappes et al., 2009; Lacerda et al., 2003; Pelúzio et al., 2008; Silva et al., 2017).

In the cultivar BRS 104, the mass of 100 bean grains showed a higher value in the desiccation of the plants with paraquat in relation to the one carried out with ammonium glufosinate or diquat (Table 2). However, this parameter was not affected either by the doses of the herbicide applied, nor by the date of harvest of the grains in relation to the application of the treatments. In the BRS Estilo cultivar, the mass of 100 grains was also not significantly influenced by the active ingredients of the desiccants or by the applied doses (Table 4). However, it was found that, when applying the desiccation treatments, the grains had less mass, which increased and stabilized in the three days of desiccation.

Both in the cultivar BRS 104 (Table 5) and BRS Estilo (Table 7) grain yield was not affected by the active ingredient of the desiccant or by the applied doses. This result is important, as it shows that this technology can be used to anticipate the harvest and standardize the drying of the plants without running the risk of reducing crop productivity.

Table 5 - Grain yield, seed vigor, normal and abnorma common bean seeds of cultivar BRS FC 104 as affected by the desiccant used in the pre-harvest and the applied rate.

\begin{tabular}{|c|c|c|c|c|}
\hline Factors & $\begin{array}{l}\text { Grain yield } \\
(\mathrm{kg} \mathrm{ha-1)}\end{array}$ & $\begin{array}{c}\text { Vigor } \\
\text { (\%) }\end{array}$ & $\begin{array}{c}\text { Normal } \\
\text { (\%) }\end{array}$ & $\begin{array}{c}\text { Abnormal } \\
\text { (\%) }\end{array}$ \\
\hline \multicolumn{5}{|l|}{ Desiccant } \\
\hline $\begin{array}{l}\text { Ammonium } \\
\text { glufosinate }\end{array}$ & 2,567 & 90.4 & 91.5 & 6.6 \\
\hline Paraquat & 2,606 & 94.3 & 95.7 & 2.6 \\
\hline Diquat & 2,333 & 93.8 & 94.6 & 3.5 \\
\hline Control & 2,479 & 95.8 & 96.5 & 1.75 \\
\hline \multicolumn{5}{|c|}{ Dose (g ai $\mathrm{L}^{-1}$ ha-1) } \\
\hline 200 & 2,685 & 93.8 & 94.7 & 3.1 \\
\hline 400 & 2,505 & 92.7 & 94.0 & 3.9 \\
\hline 600 & 2,317 & 91.9 & 93.1 & 5.7 \\
\hline Factors & \multicolumn{4}{|c|}{ F probability $(p<0.05)$} \\
\hline $\begin{array}{l}\text { Desiccant } \\
\text { (DE) }\end{array}$ & ns & ns & $\mathrm{ns}$ & * \\
\hline Dose (Ds) & ns & ns & $\mathrm{ns}$ & $\mathrm{ns}$ \\
\hline$D E \times D s$ & ns & * & * & * \\
\hline CV & 21.5 & 5.0 & 4.5 & 73.5 \\
\hline
\end{tabular}

ns (no significative) and * (significative). CV Coefficient of variation. Means followed by + do not differ to control treatment by the Dunnett test. 
However, it was found that for the cultivar BRS FC 104 there was a significant interaction between the type of desiccant and the application dose for the parameters vigor of seeds, normal and abnormal seedlings (Table 6). Thus, at the dosage of $600 \mathrm{~g} \mathrm{~L}^{-1}$ of the active ingredient per ha of the desiccant ammonium glufosinate, in relation to the herbicides paraquat and diquat, provided a reduction in the vigor values of seeds and normal seedlings and increased the value of abnormal common bean seedlings. Lacerda et al. $(2003,2005)$ observed that the germination of seeds from plants dried with ammonium glufosinate was lower, when compared with the drying done with paraquat, diquat and their mixtures. Guimarães et al. (2012) add that the application of ammonium glufosinate provided a higher percentage of abnormal seedlings, when compared to paraquat used at the same time. According to the authors, although it is also a contact herbicide, it is easier translocated into the plant than paraquat and diquat and can cause greater damage to the seed, compromising its physiological quality. However, these problems of reduced vigor and normal seedlings and increased abnormal seedlings, were only found at the dose of $600 \mathrm{~g} \mathrm{~L}^{-1}$ of the active ingredient per ha and only in the cultivar BRS FC 104.

In conclusion, the use of dessicants reduced the period of harvesting in four days in both cultivars (BRS FC 104 and BRS Estilo). Paraquat, diquat and ammonium glufosinate with the rate of $200 \mathrm{~g} \mathrm{~L}^{-1}$ of ai per ha in the super early life cycle cultivar BRS FC 104 and 1,440 $\mathrm{g} \mathrm{L}^{-1}$

Table 6 - Seed vigor, normal and abnormal seedlings influenced by the interaction between the type of

desiccant used in the pre-harvest of common bean cultivar BRS FC 104 and the dose used in desiccation.

\begin{tabular}{|c|c|c|c|}
\hline \multirow{3}{*}{ Desiccant } & \multicolumn{3}{|c|}{ Dose (g ai L-1 ha-1) } \\
\hline & 200 & 400 & 600 \\
\hline & \multicolumn{3}{|c|}{ Seed vigor (\%) } \\
\hline Ammonium glufosinate & $95.0 \mathrm{aA}$ & $91.8 \mathrm{aAB}$ & 84.5 bB \\
\hline Paraquat & 93.5 aA & 93.8 aA & 95.5 aA \\
\hline \multirow[t]{2}{*}{ Diquat } & $93.0 \mathrm{aA}$ & 92.8 aA & 95.8 aA \\
\hline & \multicolumn{3}{|c|}{ Normal seedlings (\%) } \\
\hline Ammonium glufosinate & 96.3 aA & 92.3 aAB & $86.0 \mathrm{bB}$ \\
\hline Paraquat & 95.0 aA & 95.3 aA & 96.8 aA \\
\hline \multirow[t]{2}{*}{ Diquat } & 92.8 aA & 94.5 aA & $96.5 \mathrm{aA}$ \\
\hline & \multicolumn{3}{|c|}{ Abnormal seedlings (\%) } \\
\hline Ammonium glufosinate & $2.3 \mathrm{aB}$ & $5.3 \mathrm{aB}$ & 12.3 aA \\
\hline Paraquat & $2.8 \mathrm{aA}$ & $2.5 \mathrm{aA}$ & $2.5 \mathrm{bA}$ \\
\hline Diquat & $4.3 \mathrm{aA}$ & $4.0 \mathrm{aA}$ & $2.3 \mathrm{bA}$ \\
\hline
\end{tabular}

Means followed by the same letter, lower case in the column or upper case in the row, do not differ by Tukey's test $(p<0.05)$.
Table 7 - Grain yield, seed vigor, normal and abnormal common bean seeds of cultivar BRS Estilo as affected by the desiccant used in the pre-harvest and the applied rate.

\begin{tabular}{|c|c|c|c|c|}
\hline Factors & $\begin{array}{l}\text { Grain } \\
\text { yield } \\
\text { (kg ha-1 }\end{array}$ & $\begin{array}{l}\text { Vigor } \\
\text { (\%) }\end{array}$ & $\begin{array}{c}\text { Normal } \\
\text { (\%) }\end{array}$ & $\begin{array}{c}\text { Abnormal } \\
\text { (\%) }\end{array}$ \\
\hline \multicolumn{5}{|l|}{ Desiccant } \\
\hline $\begin{array}{l}\text { Ammonium } \\
\text { glufosinate }\end{array}$ & 3,420 & 91.4 & 93.9 & 1.7 \\
\hline Paraquae & 3,459 & 86.4 & 89.5 & 6.8 \\
\hline Diquat & 3,551 & 89.2 & 90.9 & 4.9 \\
\hline Glyphosate & 3,657 & 89.3 & 92.3 & 6.2 \\
\hline Contol & 3,566 & 88.5 & 93.5 & 3.0 \\
\hline \multicolumn{5}{|l|}{ Dose (g ae/ai L-1 ha-1) } \\
\hline $\begin{array}{l}200 \text { for other des- } \\
\text { sicants and } 480 \\
\text { for glyphosate }\end{array}$ & 3,550 & 87.4 & 89.9 & 5.3 \\
\hline $\begin{array}{l}400 \text { for other des- } \\
\text { sicants and } 960 \\
\text { for glyphosate }\end{array}$ & 3,552 & 89.6 & 91.9 & 4.9 \\
\hline $\begin{array}{l}600 \text { for other des- } \\
\text { sicants and } 1,440 \\
\text { for glyphosate }\end{array}$ & 3,464 & 90.3 & 93.1 & 4.4 \\
\hline Factors & \multicolumn{4}{|c|}{ F probability $(p<0.05)$} \\
\hline Dessicant (DE) & ns & ns & ns & ns \\
\hline Dose (Ds) & ns & ns & ns & ns \\
\hline$D E \times D s$ & ns & ns & ns & ns \\
\hline CV & 13.2 & 11.2 & 9.8 & 174,2 \\
\hline
\end{tabular}

ns (no significative) and * (significative). CV Coefficient of variation. Means followed by + do not differ to control treatment by the Dunnett test.

of ae per ha for glyphosate and $600 \mathrm{~g} \mathrm{~L}^{-1}$ of ai per ha for the others dessicants in the normal life cycle cultivar BRS Estilo were the best dose used. The use of desiccants in common bean plants cultivars BRS FC 104 and BRS Estilo did not affect the grain yield of the crop. The dosage of 600 $\mathrm{g} \mathrm{L}^{-1} \mathrm{ha}^{-1}$ of the ammonium glufosinate desiccant provided a reduction in vigor and normal seedlings and an increase in abnormal seedlings in the cultivar BRS FC 104.

\section{Author' contributions}

JGS: performed the trial and contributed in the writing of the manuscript. ASN: made statistical analyses and write the manuscript. PHLS: contributed in the conducting of the trial.

\section{Funding}

This research was founded by Embrapa Rice and Beans and MIAC company.

\section{References}

Assis MO, Araujo EF, Freitas FCL, Silva LJ, Araujo RF. Pre-harvest desiccation in productivity and physiological quality of cowpea seeds. Planta Daninha. 2019;37:1-11. Available from: https://doi.org/10.1590/s0100-83582019370100014
Brunharo CACG, Christoffoleti PJ, Nicolai M. [Aspects of the mechanism of action of the ammonium glufosinate: resistant crops and resistance of weeds]. R Bras Herb. 2014;13(2):163-77. Portuguese. Available from: https://doi.org/10.7824/rbh.v13i2.293 
Coelho CMM, Coimbra JLM, Souza CA, Bogo A, Guidolin AF. [Genetic diversity in common bean accessions] Cienc Rural. 2007;37(5):1241-7. Portuguese. Available from: https://doi.org/10.1590/S0103-84782007000500004

Coelho CMM, Souza CAS, Zilio M, Michels AF. [The effect of pre-harvest desiccation ontheyieldand physiological quality oflandracebean seeds] Semina Cienc Agrar. 2012;33(Suppl.1):2973-80. Portuguese. Available from: https://doi.org/10.5433/1679-0359.2012v33n6Supl1p2973

Companhia Nacional de Abastecimento - Conab. [Harvest bulletins] Brasília, DF: Ministério da Agricultura; 2020[access April 27, 2020]. Portuguese. Available at: https://www.conab.gov.br/info-agro/safras

Daltro EMF, Albuquerque MCF, França Neto JB, Guimarães SC, Gazziero DLP, Henning AA. [Pre-harvest desiccation: effects on the physiological quality of soybean seed]. Rev Bras Sementes. 2010;32(1):111-22. Portuguese. Available from: https://doi.org/10.1590/S0101-31222010000100013

Donagema GK, Campos DVB, Calderano SB, Teixeira WG, Viana JHM. [Manual of soil analyses methods]. 2th ed. Rio de Janeiro: Embrapa Solos; 2011. Portuguese.

Ganascini D, Laureth JCU, Mendes IS, Tokura LK, Sutil EL, Villa $B$ et al. Analysis of the production chain of bean culture in Brazil. J Agric Sci. 2019:11(7):256-67. Available from: https://doi.org/10.5539/jas.v11n7p256

Guimarães VF, Hollmann MJ, Fioreze SL, Echer MM, Rodrigues-Costa ACP, Andreotti M. [Productivity and quality of soybean seeds in function of desiccation stages and herbicides] Planta Daninha. 2012:30(3):567-73. Portuguese. Available from: https://doi.org/10.1590/S0100-83582012000300012

He YQ, Cheng JP, Liu LF, Li XD, Yang B, Zhang HS et al. Effects of pre-harvest chemical application on rice desiccation and seed quality. J Zhejiang Univ Sci B. 2015;16(10):813-23. Available from: https://doi.org/10.1631/jzus.B1500032

Kappes C, Arf O, Ferreira JP, Portugal JR, Alcalde AM, Arf MV et al. [Physiological quality of seeds and growth of bean seedlings in relation to pre-harvest paraquat applications]. Pesqui Agropecu Trop. 2012;42(1):9-18. Portuguese. Available from: https://doi.org/10.1590/S1983-40632012000100002

Kappes C, Carvalho MAC, Yamashita OM. [Physiological potential for dessicated soybean seed with diquat and paraquat]. Sci Agr. 2009;10(1):1-6. Portuguese. Available from: https://revistas.ufpr.br/ agraria/article/download/12520/9875

Lacerda ALS, Lazarini E, Sá ME, Valério Filho WV. [Effects of desiccation on the physiological potential and sanitary condition of seeds from soybean plants]. Bragantia. 2005;64(3):447-57. Portuguese. Available from: https://doi.org/10.1590/S0006-87052005000300015

Lacerda ALS, Lazarini E, Sa ME, Valerio Filho WV. [Storage of dessicated soybean seedand theevaluation ofphysiologic, biochemicaland sanitary characteristics]. Rev Bras Sementes. 2003;25(2):97-105. Portuguese. Available from: https://doi.org/10.1590/S0101-31222003000400014
Lamego FP, Gallon M, Basso CJ, Kulczynski SM, Ruchel Q, Kaspary TE et al. [Pre-harvest application and effects on yield and physiological quality of soybean seeds]. Planta Daninha. 2013:31(4):929-38. Portuguese. Available from: https://doi.org/10.1590/S0100-83582013000400019

McNaughton KE, Blackshaw RE, Waddell KA, Gulden RH, Sikkema $\mathrm{PH}$, Gillard CL. Effect of application timing of glyphosate and saflufenacil as desiccants in dry edible bean (Phoseolus vulgaris L.). Can J Plant Sci. 2015;95(2):369-75. Available from: https://doi.org/10.4141/cjps-2014-157

Melo LC, Del Peloso MJ, Pereira HS, Faria LC, Costa JGC, Diaz JLC et al. [BRS estilo: cultivar of 'Carioca' grain type, with erect architecture associated to high yield potential]. Santo Antônio de Goiás: Embrapa Arroz e Feijão; 2009. Portuguese.

Melo LC, Pereira HS, Souza TLPO, Faria LC, Aguiar MS, Sfeir A et al. [BRS FC104: super early 'Carioca' cultivar of common bean]. Santo Antônio de Goiás: Embrapa Arroz e Feijão; 2017. Portuguese.

Muasya RM, lommen WJM, Struik PC. Differences in development of common bean (Phoseolus vulgaris L.) crop and fractions within a crop: II seed viability and vigour. Field Crop Res. 2002;75(1):79-89. Available from: https://doi.org/10.1016/S0378-4290(02)00014-X

Pelúzio JM, Ramo LN, Fidelis RR, Afférri FS, Castro Neto MD, Correia MAR. [Influence of the chemistry dessication and harvest delaying of the quality phisiological of seed in soybean in south of the Tocantins State]. Biosci J. 2008;24(2):77-82. Portuguese. Available from: http://www.seer.ufu.br/index.php/biosciencejournal/article/ view/6996/4637

Santos JB, Ferreira EA, Ferreira EM, Silva AA, Ferreira LR. [Effects of bean plant desiccation on quality of stored seeds]. Planta Daninha. 2005;23(4):645-51. Portuguese. Available from: https://doi.org/10.1590/S0100-83582005000400012

Silva JG, Machado IT, Nascente AS. [Evolution and perspectives of mechanized harvesting of common bean]. Inform Agropec. 2017:38(298):61-9. Portuguese.

Silva MR, Rosa HA. [Comparison between desiccation times using herbicide in pre-harvest soybean]. Rev Cultiv Saber. 2016;9(4):4618. Portuguese. Available from: https://www.fag.edu.br/upload/revista/ cultivando_o_saber/58542c44c1419.pdf

Silva PC, Ronchi Filho PCC, Santos PHV, Moraes N, Monquero PA, Dias R et al. [Desection of bean culture through herbicides for harvest anticipation]. Rev Ensaios Pioneiros. 2017;1(1):14-25. Portuguese. Available from: https://doi.org/10.24933/rep.v1i1.33

Silveira PM, Stone LF. [Common bean crop irrigation]. Santo Antônio de Goiás: Embrapa Arroz e Feijão; 2001. Portuguese.

Sousa DMG, Lobato E. [Cerrado: soil correction and fertilization]. Planaltina: Embrapa Cerrados; 2004. Portuguese.

Souza LH, Vieira LB, Fernandes HC, Lima JSS. [Evaluation of noise levels emitted by a bean pick-up machine]. Eng Agric. 2004;24(3):745-9. Portuguese. Available from: https://doi.org/10.1590/S0100-69162004000300027 
Tavares CJ, Ferreira PC, Jakelaitis A, Sales JF, Resende O. Physiological and sanitary quality of desiccated and stored azuki bean seeds. Rev Caatinga. 2016;29(1):66-75. Available from: https://doi.org/10.1590/1983-21252016v29n108rc

Vieira C. [Common bean crop]. 2th ed. Viçosa: Universidade Federal de Viçosa; 2006. Portuguese.
Zagonel J, Venancio WS, Sousa Neto AM. [Diquat defoliation efficiency on pre harvest bean crop]. Rev Bras Herbicidas. 2002;3(1):17-21. Portuguese. Available from: https://doi.org/10.7824/rbh.v3i1.366 